\title{
USE OF ICTS AMONG FISH FARMERS IN OYO STATE
}

\author{
Akinbile L.A. and Alabi O. E \\ Department of Agric Extension and Rural Development \\ University of Ibadan, Ibadan \\ E-mails: lakinbile@yahoo.com; flakyonline@yahoo.com \\ Mobile: +2348023250454
}

\begin{abstract}
The need to reduce the import bill on fish through improved fish farming in order to meet its increasing demand led to enhancement of local production. This is through improving capacity of fish farmers with the use of Information Communication Technologies (ICTs). In determining the use of ICTs among fish farmers in Oyo State, one hundred and twenty respondents were interviewed for the study. These were selected from Ibadan/lbarapa zone of Oyo State ADP using simple random sampling technique. The relationship between use of ICTs and income level was determined using PPMC. Results show that 89.2 percent of the respondents were married and 84.2 percent were educated with mean age of 46 years. The registered farmers updated their knowledge often from different sources, most especially from extension agents. The use of ICTs by respondents indicated a significant relationship with their income level $(r=0.264, p=0.004)$. The study concluded that fish farmers' behaviour to information is not poor but they do not have enough knowledge of ICTs, especially the modern ones which will make them exploit the potentials embedded in the use. Therefore there should be enough sensitization of fish farmers on the importance and advantages of the use of ICTs.
\end{abstract}

\section{Introduction}

Generally, agriculture is an information-intensive industry. The sector draws upon infinite sources of widely dispersed, locally contextualized knowledge and a considerable body of research materials. It relies upon continuous flow of information from local, regional and world markets (Rutger, 2000). It involves such sub-sectors as fish farming, crop production and livestock rearing. Fish farming has become a common practice to increase income of practitioners and in the process reduce the wage bill expended on fish importation. Fish farmers thus need information to optimize production. Due to the growing population of fish farmers, different kinds of information are being made available to those interested, particularly on how to start fish farming, management of fish farming and what to do when one is at a cross road. Seminars and workshops are often organized to enlighten and educate people on fish farming management practices. Information and communication technologies are also being used in information dissemination on the subject matter. All these are to encourage local participation so as to increase rate of production.

Michels and Vancrowther (2001) defined ICTs as a range of electronic technologies which when converged in a new configuration are flexible, adaptable, enabling and capable of transforming organizations and redefining social relations. Information communication technologies (ICTs) are set of activities that facilitate the capturing, storage, processing, transmission and display of information by electronic means (Olowokere, 2006). The range of technologies is increasing all the time and there is convergence between the new and old media. The new media are computers, mobile phones and the internet, while the old media include radio, television, telephone and fax among others. According to Hafkin and Odame (2002), 
ICTs are individual or set of technologies that include both new and old equipment for human and digital communication. They contend that the information carriers are used in new ways and that the convergence of the new and old media in ICTs is the best. Currently, there are phones with radio, media centres with computing capabilities and digital television.

Kiplangat (2003) affirms that ICTs have become a driving force in development, providing a means of narrowing the information gap between developed and developing countries and among their communities. The accessibility to information which is made readily available by ICTs has helped in moulding our attitudes towards life as there is more information about certain aspects of life including the agricultural sector (Spore, 2004). Olowokere (2006) asserted that ICTs are assumed to improve lives by making it easier to communicate and less expensive to find information. ICTs are seen as enabling tools that will help developing countries and in particular rural communities catch up with the rest of the world.

Information as a factor of production is necessary to increase productivity. It has been established that poverty in Nigeria has a strong linkage with agricultural stagnation due to decline in productivity as a result of low use of information and improved technologies (FAO, 1999). The right to information becomes as fundamental as the right to food, shelter and employment. Hence, information is seen as a factor of production for which fish farmers may be willing and prepared to pay. As reported by Meyer (2005), information plays an important role in almost every human activity and its value in the development process has been a topic of extensive debate. Lack of information has impacted negatively on the development process. Information should also be seen as being tangible, physical and concrete to fish farmers, most especially through extension services. Arokoyo (2003) revealed that the village level extension agent is the most effective source of information for farmers but certainly not the most efficient in terms of cost and coverage.

Using information is a key issue in the information age. The real challenge of our time is not producing information or storing information, but getting people to use information (Gholamreza and Naser, 2005). Timely availability of relevant information is vital for effective performance of fish farmers.

The enhancement of local fish production can be brought about by improving capacity in terms of enhancing access to information, while also the technical nature of fish farming requires that the knowledge of practitioners are constantly updated which can be achieved through their enhanced information seeking behavior by the use of ICTs. It thus becomes important to find out how use of ICTs affects fish farmers' production. Thus, the extent to which fish farmers use ICTs are ex-rayed so as to know how that affects their level of production. It is against this backdrop that this study addressed the following research objectives:

\section{Objectives of the Study}

The general objective of the study is to determine the extent of use of ICTs among fish farmers in Oyo State.

\section{Specific objectives}

The specific objectives are to;

i) describe the socio - economic characteristics of fish farmers;

ii) identify the sources of information of fish farmers;

iii) examine the level of use of ICTs among fish farmers; and 
vi) determine the income level of fish farmers in the study area.

\author{
Hypothesis of the Study \\ i) There is no significant relationship between respondents' use of ICTs and \\ their income level.
}

\title{
METHODOLOGY
}

The study was carried out in Oyo State, Nigeria. Oyo State is situated in Latitude $7^{0} 241 \mathrm{~N}$ and Longitude $3^{0} 54 \mathrm{E}$ as well as altitude $234 \mathrm{~m}$ above sea level. The target population was all registered and unregistered fish farmers in Oyo state. The Oyo State Agricultural Development Programme (OYSADEP) structure was used for the study. OYSADEP is divided into 4 zones i.e. Ibadan/lbarapa, Oyo, Ogbomoso and Shaki zones. Ibadan-Ibarapa zone was purposively selected as it has more fish farmers registered with OYSADEP than in other zones. Fish farmers under OYSADEP were registered at zonal level without further delineation to bocks and cells due to their localisation.. Simple random sampling technique was used to sample 38 percent of the 160 fish farmers registered with OYSADEP in IbadanIbarapa zone. This gave 60 registered farmers. In order to give room for good comparison, the same number of fish farmers that were not registered with OYSADEP in the zone was selected. This involved using snowball technique to compile a list of 92 fish farmers that were not registered with OYSADEP in the zone, from which 60 were randomly sampled, giving a total sample size of 120 respondents for the study.

Data were collected from respondents using interview schedule with the use of a structured questionnaire. The questionnaire was divided to two sections. The first section was on the respondents' personal characteristics while the second was on their use of ICTs. The dependent variable of the study is the extent of use of ICTs among fish farmers in Oyo State and it was measured by asking them to pick yes or no for some listed ICTs in terms of use, while frequency of use was assessed using use daily, weekly, twice weekly and monthly. Independent variables include the socio - economic characteristics of respondents which were measured by asking them to choose the one appropriate to them from listed options.

The tools that were used in analyzing data in this study were: descriptive and inferential statistics. The former includes tables, frequency distribution and mean, while the latter includes Pearson product moment correlation (PPMC). The descriptive statistical tools were used to present the specific objectives while the hypotheses were tested by using the inferential statistical tools.

\section{Results and Discussion}

\section{Distribution of socio economic characteristics of respondents}

Age distribution of respondents as shown in Table 1 indicates that many $(40.0 \%)$ of the respondents are within the age group of $36-45$ years, while the least group $(0.8 \%)$ is composed of respondents whose age range between 66 and 75 years. The implication is that majority of the fish farmers are in their middle age. Therefore, they have the ability to search for information on fish farming and are more ready to take risk. They also have the agility required for effective fish farming. Also, 89.2 percent are married, 5.0 percent are widowed and 5.8 percent are single. This implies that married people are more involved in fish farming and this could be 
as a result of more responsibilities they are saddled with as married people who have responsibility for the provision of household needs of their families.

Majority of the respondents (70.0\%) are Christians while 30.0 percent are Muslims. Religion may play a role in the income generating activities of both rural and urban dwellers. Majority of the respondents had OND/NCE (31.7\%) and HND/B.Sc./M.Sc (32.5\%). The implication is that most of the respondents have formal education and are likely to have a positive attitude toward information seeking. This may be because of the technicality of fish farming which involves the intricacies of fish culture. This is in line with the findings of Adeleke (2006) that most fish farmers have formal education.

Table1: Distribution of respondents according to their socio-economic characteristics $(n=120)$

\begin{tabular}{lcc}
\hline \multicolumn{1}{c}{ Characteristic } & Frequency & Percentage \\
\hline Age & 14 & \\
$26-35$ & 48 & 11.7 \\
$36-45$ & 32 & 40.0 \\
$46-55$ & 25 & 26.7 \\
$56-65$ & 1 & 20.8 \\
66 and above & & 0.8
\end{tabular}

\section{Educational Attainment}

Pry school attempted

Pry school completed

$4 \quad 3.3$

Sec.school attempted $\quad 6 \quad 5.0$

Senior school certificate $\quad 21 \quad 17.5$

$\begin{array}{lll}\text { OND/NCE } & 38 & 31.7\end{array}$

HND/B.Sc/M.Sc $39 \quad 32.5$

$\begin{array}{lll}\mathrm{PHD} & 3 & 2.5\end{array}$

\section{Marital Status}

$\begin{array}{lcc}\text { Married } & 107 & 89.2 \\ \text { Single } & 7 & 5.8 \\ \text { Widowed } & 6 & 5.0 \\ \text { Religion } & & \\ \text { Christianity } & 84 & 70.0 \\ \text { Islam } & 36 & 30.0\end{array}$

Income level

Table 2 shows that 16.9 percent of the respondents achieved income level of between $\mathrm{N} 15,000$ and $\mathrm{N} 175,999$ per production year, 15.8 percent have production output of between $\mathrm{N} 377,000$ and $\mathrm{N} 497,999$. The maximum income level ranges from $\mathrm{N} 1,303,000$ - $\mathrm{N} 1,463,999$ (for 6.8 percent). The mean income level was $\mathrm{N}$ 537,224 . The implication is that majority of the respondents produce at low level. 
This may be as a result of lack of useful information which could help them increase their production output

Table 2: Income level of respondents $(n=120)$

\begin{tabular}{|c|c|c|}
\hline Income $(\mathrm{N})$ & Frequency & Percent \\
\hline $15,000-175,999$ & 20 & 16.9 \\
\hline $176,000-336,999$ & 9 & 7.5 \\
\hline $377,000-497,999$ & 19 & 15.8 \\
\hline $498,000-658,999$ & 13 & 10.8 \\
\hline $659,000-819,999$ & 6 & 5.1 \\
\hline $820,000-980,999$ & 13 & 10.8 \\
\hline $981,000-1,141,999$ & 12 & 9.9 \\
\hline $1,142,000-1,302,999$ & 12 & 9.9 \\
\hline $1,303,000-1,463,999$ & 8 & 6.8 \\
\hline Mean income level & N537,224 & \\
\hline
\end{tabular}

\section{Sources of information of respondents}

Table 3 reveals that the respondents source for information from four major sources; fisheries experts, mass media, extension agents and friends, while they rarely source for information through ICTs. Majority of the respondents' source information from extension agents on all the activities involved in fish farming. On pond construction, 4.2 percent seek information from fisheries experts, 11.7 percent from mass media, 47.5 percent from extension agents and 5.0 percent from friends. On stocking, 2.5 percent seek information from fisheries expert, 10.0 percent from mass media, 48.3 percent from extension agents and 5.0 percent from friends. Also, 47.5percent of the respondents source information on water management from extension agents, 2.5 percent from fisheries experts and 10.0 percent from mass media. This suggests that most of the respondents source information on the various fish management practices from extension agents. This finding corroborates the significance of one-on-one contact of extension agents as the second most readily accessible source of agricultural information as in the study of Yahaya (2003).

Table 3: Sources of information of respondents

\begin{tabular}{lllllll}
\hline Sources & $\begin{array}{l}\text { Pond } \\
\text { Freq. }\end{array}$ & $\begin{array}{l}\text { const. } \\
\%\end{array}$ & $\begin{array}{l}\text { Stocking } \\
\text { Freq. }\end{array}$ & $\begin{array}{l}\text { Water } \\
\text { Freq. }\end{array}$ & $\begin{array}{l}\text { managt. } \\
\%\end{array}$ \\
\hline $\begin{array}{l}\text { Fisheries } \\
\text { experts }\end{array}$ & 5 & 4.2 & 3 & 2.5 & 3 & 2.5 \\
$\begin{array}{l}\text { Mass media } \\
\text { Extension }\end{array}$ & 14 & 11.7 & 12 & 10.0 & 12 & 10.0 \\
$\begin{array}{l}\text { agents } \\
\begin{array}{l}\text { Friends/relatives } \\
\text { ICTs }\end{array}\end{array}$ & 5 & 47.5 & 58 & 48.3 & 57 & 47.5 \\
\hline
\end{tabular}

\section{Use of ICTs for updating knowledge on fish farming by respondents}

Table 4 reveals that radio is the mostly utilized ICTs for updating knowledge on fish farming as indicated by 75.0 percent of the respondents, followed by 
television with 69.2 percent. The least used is fax with 0.8 percent. This confirms the findings of Otitolaye (2006) who reported that the most important factors considered by respondents in the use of communication channels for information dissemination was cost of use and accessibility, as the ICTs that are expensive to acquire are least used by respondents, while cheap ones like radio are often used. This is also in line with the findings of Eniolorunda (1999) that radio is most widely used because radio sets are cheaper to purchase, easy to maintain and lasts longer. In addition, Onah (2006) reported that radio is unique in that it is relatively inexpensive to set up.

Table 4: Use of ICTs for updating knowledge on fish farming by respondents

\begin{tabular}{lllll}
\hline ICTs & Yes & Partially & No & Mean \\
\hline Radio & $90(75.0)$ & $28(23.3)$ & $2(1.7)$ & 1.52 \\
Television & $83(69.2)$ & $4(3.3)$ & $33(27.5)$ & 1.42 \\
Computer & $16(13.3)$ & $10(8.3)$ & $94(78.3)$ & 0.35 \\
Internet & $14(11.7)$ & $16(13.3)$ & $90(75.0)$ & 0.37 \\
Telephone & $73(60.8)$ & $11(9.2)$ & $36(30.0)$ & 1.31 \\
Fax & $1(.8)$ & $4(3.3)$ & $115(95.8)$ & 0.05 \\
Video & $65(54.2)$ & $7(5.8)$ & $48(40.0)$ & 1.14 \\
Newspaper & $74(61.7)$ & $7(5.8)$ & $39 \mathrm{~s}(32.5)$ & 1.29 \\
\hline
\end{tabular}

\section{Source - Survey data, 2006}

\section{Frequency of use of ICTs for updating knowledge on fish farming by respondents}

The frequency of use of these ICTs among the respondents shows how often these ICTs are being used for updating knowledge on fish farming. It is categorized into daily, weekly, twice weekly and monthly as seen below. It was discovered that radio has the highest frequency of use on a daily basis with 73.3 percent, followed by telephone with 71.1 percent. This confirms the assertion of Greenberg (2005) that mobile phone communication is now widely available and can be accessed at a modest cost. In the case of television, the highest percentage of the user falls within the daily category with 61.7 percent, while the lowest percentage falls within the twice weekly category with 2.5 percent. The internet has the highest frequency of those used monthly as it was indicated by 79.1 percent. The highest frequency of use of newspaper falls within the daily users with 52.5 percent. Video is used daily and monthly with 20.8 percent and 71.1 percent respectively. On the other hand, the ICT that has the lowest level of patronage is fax as only few people responded to its use.

In summary, seven of the ICTs are being used daily, weekly and twice weekly, these are radio, television, computer, internet, telephone, video and newspaper, while the eight (including fax) are used monthly. 
Table 5: Frequency of use of ICTs*

\begin{tabular}{lllll}
\hline ICTs & Daily & Weekly & $\begin{array}{l}\text { Twice } \\
\text { weekly }\end{array}$ & Monthly \\
\hline Radio & $88(73.3)$ & $20(16.7)$ & $8(6.7)$ & $4(3.3)$ \\
Television & $74(61.7)$ & $17(14.2)$ & $3(2.5)$ & $26(21.6)$ \\
Computer & $16(13.3)$ & $14(11.7)$ & $7(5.8)$ & $83(69.1)$ \\
Internet & $9(7.50$ & $11(9.2)$ & $5(4.2)$ & $95(79.1)$ \\
Telephone & $86(71.1)$ & $2(1.7))$ & $7(5.8)$ & $25(20.9)$ \\
Fax & & & & $120(100)$ \\
Video & $25(20.8)$ & $2(1.7)$ & $7(5.8)$ & $86(71.7)$ \\
Newspaper & $63(52.5)$ & $24(20.0)$ & $14(10.8)$ & $20(16.7)$ \\
\hline
\end{tabular}

${ }^{*}$ Percentages in parenthesis

Relationship between income level of respondents and their use of ICTs.

Table 6 shows that there is a significant relationship $(r=0.264)$ between income level of respondents and their use of ICTs. This suggests that usage of ICTs brings about significant change in income level of respondents. Thus, the more the respondents use ICTs, the higher is their income level i.e. those that attain higher income level are those that use more of ICTs. Therefore, the null hypothesis which states that there is no significant relationship between income level of respondents and their use of ICTs is rejected. Thus, fish farmers that make use of ICTs have their income enhanced as they achieve higher income level.

Table 6: Correlation analysis of income level of respondents and their use of ICTs.

\begin{tabular}{|lccc|}
\hline Variables & Correlation & P Sig (2 tailed) & Decision \\
\hline $\begin{array}{l}\text { Use of ICTs } \\
\text { Vs }\end{array}$ & 0.264 & 0.004 & $\mathrm{~S}$ \\
\hline
\end{tabular}

\section{Conclusion}

The study concluded that majority of fish farmers source information from extension agents on various fish farming management practices. The findings also showed that usage of ICTs increases the respondents' income level. However, the fish farmers require a level of knowledge that will make them exploit the potentials embedded in the use of ICTs. There is not enough sensitization on the importance and advantages attached to the use of these ICTs. The farmers' attitude to information is not poor, and beyond being aware of these ICTs, they need to know the benefits of its usage.

\section{Recommendations}

Based on the findings of this study, the following recommendations are made;

- Extension agents should be used to orientate the farmers about ICTs and the benefits to be derived from its use

- $\quad$ Farmers should be adequately trained on how to use ICTs and this could be done by establishing training centers in strategic locations in the state.

- Economically feasible and sustainable access points should be located at farmers' reach 
- ICTs should be made available and affordable to all farmers. This will encourage them to develop a positive attitude to seeking information relevant to their needs.

\section{References}

Adeleke B.A (2006): Aquaculture technology awareness, transfer and adoption among fish farmers in Oyo town and its environs. An unpublished M.Sc thesis University of Ibadan. Ibadan. Pp 35

Arokoyo T (2003): Response to the e-discussion: ICT Applications in Rural Extension and Information Exchange. In Bokre, D and Ballantayne T, INARSICTs Transforming Agricultural Extension CTA Observatoryon ICTs. $6^{\text {th }}$ Consultative Expert Meeting, Wageningen.

Eniolorunda P.A (1999): Assessment of Nigerian-German Kainji Lake Fisheries Promotion Projects Radio Programme on Fisherman's Utilization of Recommended Practices. An unpublished M.Sc thesis. University of Ibadan. Ibadan

FAO (1999): The State of World Fisheries and Aquaculture. 1998 Food and Agriculture Organisation, Rome, Italy

Gholamreza P. and Naser.Z. (2005): Information-seeking behaviour of Iranian extension managers and specialists. FAO, Rome Pp 36

Hafkin, N.J. and H.H. Odame (2002): Gender, ICTs and Agriculture. A Situation Analysis for the 5t Consultative Expert Meeting of CTA's ICT Observatory Meeting on Gender and Agriculture in Information Society, August 2002. pp $10-25$

Kiplangat (2001):. The role of telecentres in the provision of agricultural information for rural development in Sub-Saharan Africa. IAALD quarterly Bulletin 46 $(3 / 4): 81-86$.

Marker P.K., Mc Namara, and L. Wallace (2002): The significance of Information and Communication Technologies for reducing poverty. Department for International Development (DFID) London, UK.

Meyer H.W.J (2005): The Nature of Information, and the Effective Use of Information in Rural development. National Agriculture Extension \& Research Liaison Services (NAERLS, 2001): Field Situation Assessment of 2001 Wet Season Agriculture Production in Nigeria Ahmadu Bello University, Zaria.

Michels, S.I. and L. Vancrowther. D. (2001): Discovering the magic Box: Local Appropriation of Information and Communication Technologies (ICTs): SDRE, FAO, pp. $4-5$.

Olowokere, G.T. (2006): Use of ICTs among rural dwellers in Oyo-State. An Unpublished B.Sc. thesis, University of Ibadan. Pp. 2, 10, 11.

Onah H.B (2006): Use of Information Communication Technologies (ICTs) by public and private extension agencies in Oyo State

Otitolaye O.O (2006): Assessment of Extension Agents' Knowledge in the Use of Communication Channels for Agricultural Information Dissemination in Ogun State. An Unpublished B.Sc. thesis, University of Ibadan. Pp. 2, 10, 11.

Practical Action - ICTs Research and Strategy.

http//www.worldfish centre.org/redirect.aspx? dd//D = 80\$catID = 3224k. Retrieved 08/12/06.

Rutger. J.E. (2000):. Technical. Policy and Institutional Trends in Information and Communication. Proceedings of a CTA Seminar. 
Spore (2004): Information for Agricultural Development in ACP countries.No. 110. pp $4-5$.

Talero, E and Gaudette, P. (1995): 'Harnessing information for development: A proposal for a World Bank Group Strategy'. Discussion Paper No. 313.

Yahaya M. k (2003): Development Communication. Lessons from Change and Social Engineering Projects. Corporate Graphics Ltd, Ibadan. Nigeria.

Yekini O.T (2006): Determinants of adoption of Information and Communication Technologies (ICTs) for agricultural extension delivery and rural development in Nigeria. An unpublished Ph.D thesis University of Ibadan. Ibadan. Pp 24 